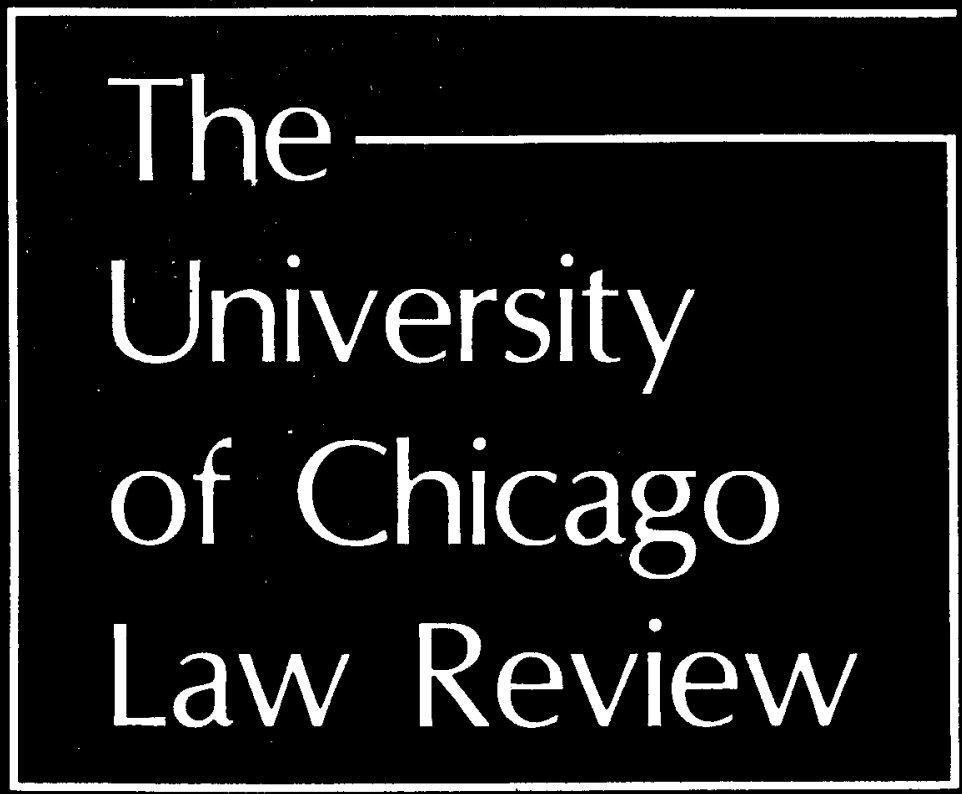

VOLUME 56

NUMBER 4

FALL 1989

A Critique of the Reasonable

Expectations Doctrine

Stephen J. Ware

๑ 1989 by The University of Chicago 


\title{
A Critique of the Reasonable Expectations Doctrine
}

\author{
Stephen J. Ware $†$
}

\begin{abstract}
INTRODUCTION
Traditionally, courts interpreting written contracts focused primarily on the contract's language. Consideration of factors beyond the "four corners" of the document was discouraged. Modern courts construing standard form insurance contracts have deviated from this course and begun aiding the insured against the insurer. One of the methods used to tilt insurance disputes in favor of the insured is the "reasonable expectations doctrine," described by Professor (now Judge) Robert Keeton in this "classic"
formulation:1
\end{abstract}

The objectively reasonable expectations of applicants and intended beneficiaries regarding the terms of insurance contracts will be honored even though painstaking study of the policy provisions would have negated those expectations. ${ }^{2}$ Academic commentary almost uniformly supports the reasonable expectations doctrine. ${ }^{3}$ In the two most recent law review articles discussing the doctrine, Professor Rahdert explicitly endorses it ${ }^{4}$ and Professor Mayhew takes its legitimacy for granted and merely seeks a more principled application. ${ }^{5}$ In contrast, this Comment arChicago.

$\dagger$ B.A. 1987, University of Pennsylvania; J.D. Candidate 1990, The University of
tago. tions doctrine."

Rev 961, 967 (part, Insurance Law Rights at Variance with Policy Provisions, 83 Harv L

${ }^{3}$ An exception is \& 1281 (part 2) (1970).

Doctrine of Reasonable Expectatione Reconstruction of Insurance Contracts Under The fers "statutes mandating comprehens, 18 John Marshall L Rev 155, 176 (1984), which preexpectations doctrine. A partial exception standard insurance contracts" to the reasonable of Reasonable Expectations as Applied is Note, A Reasonable Approach to the Doctrine 620-21 (1980), which advocates confining to Insurance Contracts, 13 U Mich J L Ref 603, language. (1986).
(Mark C. Rahdert, Reasonable Expectations Reconsidered, 18 Conn L Rev 323, 373 "Mark C. Rahdert, Reasonable Expectations Reconsidered, 18 Conn L Rev 323, 373
(1986).

S William A. Mayhew, Reasonable Expectations: Seeking A Principled Application, 13 
gues that the reasonable expectations doctrine should be abandoned.

Section I of this Comment will examine the "perceived problems-inequality of bargaining power and complex standard form policies-that gave rise to the reasonable expectations doctrine. Section II will examine state law, identifying three approaches to insurance contract interpretation applied under the name "reasonable expectations doctrine." In section III, this Comment will argue that replacing policy language with the "reasonable expectations" of the insured is unwarranted. Economic analysis indicates that the concerns motivating advocates of the reasonable expectations doctrine-inequality of bargaining power and complex standard form policies-are really not problems at all. And, as section III will show, even if such characteristics of the insurance contract relation were problems, they could not be solved without sacrificing the values of economic efficiency, freedom of contract, and the rule of law.

The fate of the reasonable expectations doctrine is obviously important for the law of insurance contracts. Though Professor Mark Rahdert has suggested that the doctrine may be in decline, ${ }^{6}$ twenty-seven states have espoused some version of the doctrine. ${ }^{7}$

${ }^{6}$ Rahdert, 18 Conn L Rev at 324 (cited in note 4).

7 States applying the rule are discussed in the text at notes 32-66.

The following states have not adopted the doctrine. (1) Arkansas. (2) Florida. (3) Georgia. (4) Kansas: but see Western Casualty and Surety Co. $v$ Trinity Universal Insurance Co., 13 Kan App 2d 133, 764 P2d 1256, 1261 (1988) (stating that "[i]nsurers may not use unclear policy clauses to defeat the coverage reasonably expected by the insured"). (5) Louisiana: Marsh u Reserve Life Insurance Co., 516 S2d 1311, 1314 (La App 1987); but see Falgout $v$ Wilson, $531 \mathrm{~S} 2 \mathrm{~d}$ 492, 493 (La App 1988) (noting that holder of automobile liability insurance policy "has a reasonable expectation of coverage for driving while intoxicated unless such coverage is expressly excluded"). (6) Maryland: but see Government Employees Insurance Co. $\cup$ Ropka, 74 Md App 249, 536 A2d 1214, 1223, (1988) (holding that insured has right to expect renewal policy will be substantively similar to former policy because this rule is "consonant with [an insured's] reasonable expectations"). (7) Massachusetts: Jefferson Insurance Co. of New York v City of Holyoke, 23 Mass App 472, 503 NE2d 474, 478 (1987) (noting that the reasonable expectations "doctrine does not appear to have been explicitly adopted in Massachusetts"); but see Commerce Insurance Co. v Koch, 25 Mass App 383, 522 NE2d 979, 982 n 11 (1988) (quoting Keeton's version of the reasonable expectations doctrine and stating that Massachusetts "courts have been receptive to [that] proposition, although its shape has not been finally settled"); see also Note, The Doctrine of Reasonable Expectations in Massachusetts and New Hampshire: A Comparative Analysis, 17 New England L Rev 891 (1981-82). (8) Mississippi. (9) North Dakota: Walle Mutual Insurance Co. $v$ Sweeney, 419 NW2d 176, 180 (ND 1988) (explains rules for interpreting insurance policies but does not mention doctrine); but see Mills v Agrichemical Aviation, Inc., 250 NW2d 663, 673 (ND 1977) (earlier case using reasonable expectations doctrine). (10) Oklahoma: Anderson v Continental Assurance Co. 666 P2d 245, 248 (Okla App 1983); but see Massachusetts Bay Insurance Co v Gordon, 708 F Supp 1232, 1235 (W D Okla 1989) 
Furthermore, since it is estimated that over $99 \%$ of all consumer contracts are standard form contracts, ${ }^{8}$ the issues addressed in this Comment reach to the heart of modern contract law.

\section{The Perceived Problem of "Adhesive" Insurance Contracts}

\section{A. The Standard Form Insurance Policy as Adhesion Contract}

Impartial application of contractual language vanished when courts concluded that insurance contracts, at least in the consumer context, were markedly different from the type of document contemplated by traditional contract rules. Proponents of the reasonable expectations doctrine cite three distinguishing factors in the formation of a typical insurance contract. First is the likelihood that the insurance purchaser will not receive the actual contract, the insurance policy, until after offering to buy insurance and per-

(stating, without specific reference to Oklahoma law, that "insurance policies are construed so as to protect the reasonable expectations of the insured"). (11) Oregon: Western Fire Insurance Co. $v$ Wallis, 289 Or 303, 613 P2d 36, 40 (1980) (Tongue dissenting and criticizing majority for failure to adopt the reasonable expectations doctrine). (12) South Carolina. (13) South Dakota: Grandpre u Northwestern National Life Insurance Co., 261 NW2d 804, 813 (SD 1977) (Porter dissenting and advocating the reasonable expectations doctrine). (14) Tennessee. (15) Texas: Mary Kay Cosmetics v North River Insurance Company, 739 SW2d 608, 613-14 (Tex App 1987); but see Kulubis v Texas Farm Bureau Underwriters Insurance Co., 706 SW2d 953, 955 (Tex 1986). (16) Utah: but see Farmers Insurance Exchange v Call, 712 P2d 231, 237 (Utah 1985). (17) Vermont: but see Sanders v St. Paul Mercury Insurance Co., 536 A2d 914, 920 (Vt 1987). (18) Virginia. (19) Washington: Keenan v Industrial Indem. Ins. Co. of the Northwest, 108 Wash 2d 314, 738 P2d 270, 275 (1987); but see Cascade Trailer Court v Beeson, 50 Wash App 678, 749 P2d 761, 765 (1988). (20) Wyoming: but see Aetna Insurance Co. v Lythgoe, 618 P2d 1057, 1060 (Wyo 1980).

The following states have explicitly rejected the doctrine. (1) Idaho: Casey v Highlands Insurance Co., 100 Idaho 505, 600 P2d 1387, 1391 (1979); see also Aetna Casualty \& Surety Co. $v$ Gulf Resources \& Chemical Co., 1989 WL 31365 (D Idaho). (2) Illinois: Bain v Benefit Trust Life Insurance Co., 123 Ill App 3d 1025, 463 NE2d 1082, 1086 (1984) (the reasonable expectations doctrine "has not been adopted in Illinois") and American Country Insurance Co. v Cash, 171 Ill App 3d 9, 524 NE2d 1016, 1018 (1988); but see Standard Mutual Insurance Co. $v$ General Casualty Companies, 171 IIl App 3d 758, 525 NE2d 965, 967 (1988) (refusing to enforce liability policy for rental automobile because it "contradicts [the insured's] reasonable expectations" as well as public policy and an Illinois statute); see also Comment, Insurance Law-Insurance Contract Interpretation: The Doctrine of Reasonable Expectations Has No Place In Illinois, 1985 SIU L J 687, 698-99. (3) Ohio, Sterling Merchandise Co. $v$ Hartford Insurance Company, 30 Ohio App 3d 131, 506 NE2d 1192, 1197 (1986).

Note that some courts rejecting the reasonable expectations doctrine nevertheless continue to construe ambiguities against the drafter of the contract. These courts do not consider such a construction within the scope of the reasonable expectations doctrine.

${ }^{8}$ W. David Slawson, Standard Form Contracts and Democratic Control of Lawmaking Power, 84 Harv L Rev 529, 529 (1971). 
haps paying the first premium. ${ }^{\circ}$ Second is the "inequality of bargaining power" between "large, powerful and expert underwriters [and] relatively unsophisticated and dependent consumers." 10 Third is the prevalence of standard form policies, full of technical language and fine print. ${ }^{11}$ While some courts confuse these last two concerns-inequality of bargaining power and difficult standard forms - they are distinct points, since parties of equal bargaining power may use complex standard forms. ${ }^{12}$

These three factors have prompted judges and commentators to view the insurance policy as the archetypal "adhesion" contract: ${ }^{13}$ because consumers do not read their contracts and cannot negotiate the terms, advocates of the reasonable expectations doctrine assert that the consumers do not meaningfully consent to the "boilerplate" terms of standard form contracts, and therefore courts should refuse to enforce them. ${ }^{14}$

\section{B. Judicial Response to the Insurance Policy as Adhesion Contract}

Once a court decides that standard form insurance policies are "adhesion" contracts, it may attempt to favor the policyholder in a number of ways. The most common and least controversial method is the doctrine of contra proferentem, by which ambiguities in contracts are construed against the drafter. ${ }^{15}$ Virtually all courts fol-

- Keeton, 83 Harv L Rev at 968 (cited in note 2); Rahdert, 18 Conn L Rev at 329 (cited in note 4); Mayhew, 13 Pepperdine L Rev at 270-71 (cited in note 5); Zuckerman v Transamerica Insurance Co., 133 Ariz 139, 650 P2d 441, 446 (1982).

${ }^{10}$ Rahdert, 18 Conn L Rev at 326 (cited in note 4).

${ }^{11}$ Keeton, 83 Harv L Rev at 968 (cited in note 2). Storms v United States Fidelity \& Guaranty Co., $118 \mathrm{NH}$ 427, 388 A2d 578, 580 (1978) (insurance policies "ferry the unwary reader on a trip through Wonderland.").

12 See Richard A. Posner, Economic Analysis of the Law 102 (Little, Brown, 3d ed 1986).

13 Rahdert, 18 Conn L Rev at 329 (cited in note 4). The standard form insurance policy fits precisely the elaborate definition of a "contract of adhesion" in Todd D. Rakoff, Contracts of Adhesion: An Essay in Reconstruction, 96 Harv L Rev 1173, 1177 (1983).

14 Karl Llewellyn, The Common Law Tradition 370 (Little, Brown, 1960); Rahdert, 18 Conn L Rev at 337 (cited in note 4); Note, A Common Law Alternative to the Doctrine of Reasonable Expectations in the Construction of Insurance Contracts, 57 NYU L Rev 1175, 1176 (1982); Gordinier v Aetna Casualty \& Surety Co., 154 Ariz 266, 742 P2d 277, 282-83 (1987) (citations omitted) (the "typical consumer buying insurance has not assented to the myriad of essentially invisible boilerplate terms in an adhesion contract. . . . Customers submit to these terms [in standard form insurance policies] knowing that they are not and cannot be fully aware of them.").

${ }^{16}$ Restatement (Second) of Contracts $\S 206$ (1981) states: "In choosing among the reasonable meanings of a promise or agreement or a term thereof, that meaning is generally preferred which operates against the party who supplies the words or from whom a writing 
low this rule and construe ambiguities in an insurance contract against the insurer, in favor of coverage. ${ }^{16}$ Often this "ambiguity principle" is tied to the rule that insurance policies be interpreted as they would by a layperson, rather than as they would by one familiar with the insurance business. Thus, technical insurance terms-which are not ambiguous, just difficult for the layperson-may be "construed" in favor of the insured. ${ }^{17}$

The ambiguity principle "is easily the most distinguishing feature of American insurance law."18 Courts have used it to avoid what they perceive to be unfair results, fabricating ambiguities which they then construe against the insurer. ${ }^{19}$ Even an opponent of traditional "four-corners" contract interpretation admits that the ambiguity principle has been "transformed from a last-resort interpretive 'tie-breaker' into a tool of substantive policy that is intended systematically to favor the weaker party in the transaction." 20

While the ambiguity principle is a thinly concealed way of favoring the insured, courts are comfortable with it because, in form at least, it "requires no deviation from the traditional view of a written contract as the product and manifestation of mutual assent. The written word remains the controlling code, to be enforced as bargained." 21 In theory, then, parties to insurance contracts can anticipate the obligations courts will impose on them, and avoid extensions of liability through precisely drafted policies.

In addition to the ambiguity principle, courts invoke a number of other doctrines in order to favor the insured over the insurer. These include: unconscionability, estoppel, waiver, implied warranty of fitness, reformation, and public policy. ${ }^{22}$ The commentators who developed the reasonable expectations doctrine believed that these techniques insufficiently favored the insured. Moreover,

otherwise proceeds."

18 See Rahdert, 18 Conn L Rev at 328 n 15 and sources cited therein (cited in note 4).

17 See Keeton, 83 Harv L Rev at 967 (cited in note 2).

18 Rahdert, 18 Conn L Rev at 327-28 (cited in note 4).

18 "The conclusion is inescapable that courts have sometimes invented ambiguity where none existed, then resolving [sic] the invented ambiguity contrary to the plainly expressed terms of the contract document." Keeton, 83 Harv L Rev at 972 (cited in note 2).

${ }^{20}$ Rahdert, 18 Conn L Rev at 328 (cited in note 4); see also Kenneth S. Abraham, Distributing Risk: Insurance, Legal Theory and Public Policy 101 (Yale, 1986).

${ }^{21}$ Rahdert, 18 Cönn L Rev at 328 (cited in note 4).

${ }^{22}$ Mayhew, 13 Pepperdine L Rev at 268 (cited in note 5). One commentator has argued that the reasonable expectations doctrine is unnecessary because "the traditional contract law doctrines honor the insured's reasonable expectations when the insured can establish a rational basis for those expectations." Comment, $18 \mathrm{John}$ Marshall L Rev at 167 (cited in note 3$)$. 
even when application of these doctrines did lead to a result in the insured's favor, courts were forced to pay lip-service to the traditional primacy of contract language while covertly disregarding it. Advocates saw in the reasonable expectations doctrine a unifying principle that would resolve more cases in favor of the insured and would do so in an open and principled manner. ${ }^{23}$

Although the doctrine had started to grow by the 1960's, ${ }^{24}$ it did not spread rapidly until Keeton's article in $1970 .{ }^{25}$ Generally, the earlier cases invoking the reasonable expectations doctrine did little more than apply the ambiguity principle. Since courts were hesitant to admit that they were disregarding policy language, they typically found a provision "ambiguous," and then construed it in favor of the insured to protect his "reasonable expectations." Over time, however, many courts have admitted that they are using the insured's expectations not to interpret ambiguous language, but to defeat unambiguous language. ${ }^{27}$

While the reasonable expectations doctrine applies to all types of insurance, to all types of disputes, and to the commercial as well as consumer insured, ${ }^{28}$ "almost all the [reasonable expectations] cases involve ordinary consumers without a sophisticated understanding of insurance." ${ }^{29}$

\section{The Reasonable Expectations Doctrine}

Construing an insurance policy to protect the insured's "reasonable expectations" means different things to different courts.

${ }^{23}$ See Keeton, 83 Harv L Rev at 967, 972-73 (cited in note 2).

${ }^{24}$ Abraham, Distributing Risk at 103 (cited in note 20).

${ }_{25}$ "The doctrine of reasonable expectations has as its principal advocate Professor Keeton." Insurance Co. of North America v Adkisson, 121 Ill App 3d 224, 459 NE2d 310, 312 (1984).

${ }^{26}$ See Rahdert, 18 Conn L Rev at 331-32 (cited in note 4); Spencer L. Kimball, Book Review, 19 Conn L Rev 311, 314 (1987) (reviewing Kenneth S. Abraham, Distributing Risk) (finding that contract language in early reasonable expectations cases was "usually clear enough after careful study"; judges "indulge[d] in a transparent subterfuge," relying "more on ambiguity than on fairness"). See also Rakoff, 96 Harv L Rev at 1268 n 285 (cited in note 13).

${ }^{27}$ See text at notes $40-66$.

${ }^{28}$ Principles of contract interpretation favoring the insured, including the reasonable expectations doctrine, "are no less applicable merely because the insured is itself a corporate giant." CPS Chemical Co., Inc. v Continental Insurance Company, 222 NJ Super 175, 536 A2d 311, 318 (1988). See also Rahdert, 18 Conn L Rev at 347-48 (cited in note 4); but see National City Bank of Minneapolis $v$ St Paul Fire and Marine Insurance Co., 435 NW2d 57, 64 (Minn App 1989) (declining to invoke the reasonable expectations doctrine in part because the insured was a large institution with presumed equality of bargaining power).

${ }^{29}$ Abraham, Distributing Risk at 103 (cited in note 20). 
All of contract law, according to Professor Arthur Corbin, "attempts the realization of reasonable expectations that have been induced by the making of a promise." ${ }^{30}$ In this sense, courts construing contracts are always attempting to satisfy "reasonable expectations." In the insurance context, though, the phrase has acquired special meaning. Courts claiming to enforce the "reasonable expectations of the insured" may be doing any of the following three things: 1) construing an allegedly ambiguous term in favor of the insured in order to satisfy his reasonable expectations (the "ambiguity" version of the reasonable expectations doctrine); 2) refusing to enforce the "fine print" of an insurance contract because it limits a portion of the contract that is more prominent (the "fine print" version); or, 3) refusing to enforce the language of an insurance contract because doing so would frustrate the reasonable expectations of coverage that the insurer created outside of the written contract (the "whole transaction" version). These three versions of the reasonable expectations doctrine form a rough continuum from purported adherence to the policy's language to open disregard of the written contract. ${ }^{31}$

\section{A. The Ambiguity Version of the Reasonable Expectations Doctrine}

Using the insured's reasonable expectations to fill gaps left by ambiguous contract terms ${ }^{32}$ is the most cautious interpretative ap-

${ }^{30}$ Arthur Linton Corbin, Corbin on Contracts 2 (West, One Volume Edition 1952).

31 Professor Rahdert describes what he calls "weaker" and "stronger" versions of the reasonable expectations doctrine. Rahdert, 18 Conn L Rev at 335-36 (cited in note 4). The weaker version "means that an expectation formed from a cursory reading of the policy, though technically wrong, may yet be reasonable, and if so should be honored." This weaker version encompasses what this Comment calls the "ambiguity" version and, perhaps, the "fine print" version. What Rahdert calls the stronger version is "that an insured can have reasonable expectations of coverage that arise from some source other than the policy language itself, and that such an extrinsic expectation can be powerful enough to override any policy provisions no matter how clear." Id [citations omitted]. This is similar to what this Comment calls the "whole transaction" version.

${ }^{32}$ Eight states, in addition to Nevada (mentioned in the text), consider "reasonable expectations" only when interpreting ambiguous policies. (1) Connecticut: Carley v Lumberman's Mutual Casualty Co., 10 Conn App 135, 521 A2d 1053, 1057-58 (1987). (2) Indiana: Eli Lilly and Co. $v$ Home Insurance Co., 482 NE2d 467, 470 (Ind 1985); but see American Economy Insurance Company v Liggett, 426 NE2d 136, 141 (Ind App 1981) (applying the reasonable expectations doctrine to omitted term of contract). (3) Maine: Allstate Insurance Co. $v$ Elwell, 513 A2d 269, 271 (Me 1986); but see Baybutt Construction Corp. v Commercial Union Insurance Co., 455 A2d 914, 921 (Me 1983) (applying "fine print" version of reasonable expectations doctrine). (4) Missouri: the Supreme Court of Missouri has only employed the reasonable expectations doctrine in cases where the policy was ambiguous, such as Lutsky v Blue Cross Hospital Service, Inc., 695 SW2d 870, 875 (Mo 1985) (en banc); 
proach taken under the name "reasonable expectations doctrine." It is identical to the practice of construing ambiguities against the insurer except that it purports to provide an additional justification for doing so, i.e., to satisfy the insured's reasonable expectations. ${ }^{34}$

An illustration of the ambiguity version of the doctrine can be found in the Nevada Supreme Court decision, National Union Fire Insurance Co. $v$ Reno's Executive Air Inc. ${ }^{35}$ The insured helicopter owner bought an aviation policy covering liability for property damage. The policy contained an exclusion, written to conform with Civil Aeronautics Board regulations, for property "in the care, custody or control of the [insured], or carried in or on any aircraft with respect to which the insurance afforded by this policy applies." ${ }^{36}$ The insured's helicopter crashed, damaging a passenger's camera equipment. The equipment was "carried in or on" the insured aircraft so the damage to it was unambiguously excluded by the policy. But the court claimed the exclusion was ambiguous because "it does not specify in whose possession property "carried

but see Estrin Construction Co. v Aetna Casualty \& Surety Co., 612 SW2d 413, 419 (Mo App 1981) (lower court adopts the "whole transaction" version); see also Casenote, Reasonable Expectations Approach to Insurance Contract Interpretation Modified in Missouri, 47 Mo L Rev 577 (1982). (5) Nebraska: Kracl u Aetna Casualty and Surety Co,, 220 Neb 869, 374 NW2d 40, 44 (1985); see also Waylett v United Services Automobile Association, 224 Neb 741, 401 NW2d 160, 163 (1987) (rejecting consideration of extra-textual factors, since "[i]n view of the language used the plaintiff could have no reasonable expectation that the -policy did not mean exactly what it said."). (6) New Hampshire: State Farm Mutual Automobile Insurance Co. $v$ Desfosses, 536 A2d 205, 208 (NH 1987); Cacavas v Maine Bonding \& Casualty Co., $128 \mathrm{NH}$ 204, 512 A2d 423, 425 (1986). (7) New York: Ace Wire \& Cable Co., Inc. v Aetna Casualty \& Surety Co., 60 NY2d 390, 457 NE2d 761, 764 (1983); Fox v 18-05 215 Street Owners, Inc., 535 NYS2d 386, 387 (App Div 1988). (8) Rhode Island: Constant $v$ Amica Mutual Insurance Co., 497 A2d 343, 345 (1985); but see Elliot Leases Cars, Inc. $v$ Quigley, 373 A2d 810, 812 (RI 1977) (indicating that the court may be willing to overturn unambiguous contractual language). Hawaii may also consider "reasonable expectations" only when interpreting ambiguous policies: see Fortune $v$ Wong, 702 P2d 299, 306 (Hawaii 1985) (although citing Keeton, the Supreme Court announces that it is "committed to enforce ... the objectively reasonable expectations of applicants and intended beneficiaries regarding the terms of the insurance contract"); see also Sturla, Inc. v Fireman's Insurance Co., 684 P2d 960, 964 (Hawaii 1984).

${ }^{33}$ Kenneth S. Abraham, Judge-Made Law and Judge-Made Insurance: Honoring the Reasonable Expectations of the Insured, $67 \mathrm{Va}$ L Rev 1151, 1181 (1981).

${ }^{34}$ This argument is circular, as Professor Epstein has noted in another context, "because the level of expectation said to determine the rule rests in large measure upon what the rule is. .. Rules determine expectations as much as expectations determine rules." Richard A. Epstein, Defenses and Subsequent Pleas in a System of Strict Liability, $3 \mathrm{~J}$ Legal Stud 165, 204 (1974). If there were no rule construing ambiguities in favor of the insured, then it would not be reasonable to expect that.

${ }^{36} 100 \mathrm{Nev} 360,682$ P2d 1380, 1383-84 (1984).

36 Id at 1382 . 
in or on [the] aircraft' must be before the exclusion applies." 37 The court noted that the insured "reasonably expects that the policy will cover that property which is most likely to be . . . the subject of claims against the insured: the property of others carried on board the aircraft.",38

The states using the ambiguity version of the reasonable expectations doctrine are not analyzing cases any differently from states that reject the doctrine; both sets of courts claim that contractual language is crucial to their decisions, and both fabricate ambiguities or "read" the policy as a layperson would in order to provide coverage unwarranted by a precise parsing of the policy. For clarity's sake, therefore, courts and commentators should not use the term "reasonable expectations doctrine" to describe the ambiguity version. They should reserve the term for the fine print and whole transaction versions, which openly disregard policy language instead of purporting to interpret it..$^{39}$

\section{B. The Fine Print Version of the Reasonable Expectations Doctrine}

Courts using the fine print version of the doctrine refuse to enforce even clear and unambiguous contract terms that conflict with what the court determines to be the insured's reasonable expectations. ${ }^{40}$ Terms that an insured would see in glancing at the

${ }^{37}$ Id at $1382-83$.

38 Id at 1383-84.

39 Professor Rahdert has stated that the "weaker" version of the reasonable expectations doctrine (comparable to the ambiguity version advanced in this Comment) "would do little more than generate a new variant of the ambiguity principle. . . [and] would leave the policy provisions in place as the controlling code for resolving disputes over coverage." Rahdert, 18 Conn $\mathrm{L}$ Rev at 336 (cited in note 4).

40 The following states, in addition to California, Delaware, Kentucky, and Michigan (cited in the text), use the "fine print" version. (1) Alabama: Traveler's Insurance Co., Inc. $v$ Jones, 529 S2d 234 (Ala 1988). (2) Arizona: Gordinier v Aetna Casualty \& Surety Co., 154 Ariz 266, 742 P2d 277, 283-84 (1987); but see note 54 for examples of Arizona's application of the "whole transaction" version. (3) Minnesota: Atwater Creamery Co. 0 Western National Mutual Insurance Co., 366 NW2d 271, 277-78 (Minn 1985) (cites Keeton's article and adopts what it calls the "reasonable-expectations-regardless-of-ambiguity-doctrine"); see also Grinnell Mutual Reinsurance Co. $v$ Wasmuth, 432 NW2d 495, 499 (Minn App 1988), and Comment, Great Expectations for the Reasonable Expectations Doctrine, $12 \mathrm{Wm}$ Mitchell L Rev 371 $378-80$ (1986); (4) Pennsylvania: Pennsylvania's Superior Court adopted the "whole transaction" version of the doctrine in Hionis v Northern Mutual Insurance Co., $230 \mathrm{~Pa}$ Super 511, $327 \mathrm{~A} 2 \mathrm{~d} \mathrm{363,365} \mathrm{(1974),} \mathrm{but} \mathrm{the} \mathrm{holding} \mathrm{of} \mathrm{that} \mathrm{case} \mathrm{was} \mathrm{later} \mathrm{repudiated}$ by the Pennsylvania Supreme Court in Standard Venetian Blind Co. $v$ American Empire Insurance Co., $503 \mathrm{~Pa} 300,469$ A2d 563, 567 (1983); see Recent Cases, Contracts-Insurance Law-Clearly Worded and Conspicuously Displayed Exclusions in an Insurance Contract Cannot be Avoided Despite Insured's Lack of Knowledge or Under- 
policy are generally enforced, but those that are "buried" in many pages of "fine print" are likely to be disregarded. In a representative statement of the fine print version, the Delaware Supreme Court held that the insured's reasonable expectations will trump policy terms where "the policy contains a hidden trap or pitfall, or if the fine print takes away that which has been given by the large print." 11

A standard application of the fine print version appears in the California ${ }^{42}$ case, Aetna Casualty \& Surety Co. $v$ Velasco. ${ }^{43}$ The insured retailer was held liable for selling alcohol to a minor. The policy specifically excluded "injur[ies] . . . for which the insured . . . may be held liable, by reason of the selling . . . of any alcoholic beverage . . . to a minor." 44 The court admitted that the exclusion was "relatively unambiguous," but noted that it was "buried in a lengthy form contract" of twenty-three pages and that "the agent failed to mention any exclusions to [the insured]," ${ }^{45}$ and so the court read the exclusion out of the policy.

Another recent California case that applied the fine print version to defeat an unambiguous policy is Brown-Spaulding \& Associates, Inc. $v$ International Surplus Lines Insurance $C_{0}{ }^{46}$ The insured purchased professional liability insurance for the 1984

standing, 89 Dickinson L Rev 549 (1985). But the "whole transaction" version may be creeping back into Pennsylvania law. In Tonkovic v State Farm Mutual Auto Insurance Co., $513 \mathrm{~Pa} 445,521$ A2d 920, 924 (1987), the Pennsylvania Supreme Court ignored a conspicuous limitation in the policy, holding for the insured because "[c]ontrary to the facts in Venetian Blind, [the insured] here specifically requested a type of coverage that would have protected him in this instance, but was issued a policy quite different from that which he requested." See also State Auto Insurance Association v Anderson, 365 Pa Super 85, 528 A2d 1374 (1987). For a good discussion of recent Pennsylvania law on point, see Motorists Mutual Insurance Co. v Kulp, 688 F Supp 1033, 1038 (E D Pa 1988), aff'd, 866 F2d 1411 (3d Cir 1988). (5) West Virginia: Burr v Nationwide Mutual Insurance Co., 359 SE2d 626, 631. (W Va 1987); but see National Mutual Insurance Co. v McMahon \& Sons, Inc., 356 SE2d 488, 496 (W Va 1987) (asserting that the reasonable expectations doctrine applies only where the "policy language is ambiguous").

${ }^{41}$ Hallowell v State Farm Mutual Automobile Insurance Co., 443 A2d 925, 927 (Del 1982). See also Steigler v Insurance Co. of North America, 384 A2d 398, 400 (Del 1978) (applying fine print version). However, recently the court said that, absent ambiguity, there is no "authority[] for a court to apply rules of construction which require an insurance contract to be construed in favor of the insured, or attempt to discern the reasonable expectations of the purchaser." Derricksonv American National Fire Insurance Co., 538 A2d 1113, 1114 (Del 1988) (unpublished disposition; text available on Westlaw).

${ }^{42}$ See text at notes $62-65$ for a summary of California's reasonable expectations doctrine.

${ }^{43} 194$ Cal App 3d 1441, 240 Cal Rptr 290 (1987) (ordered not to be officially published).

44 Id at 291.

${ }^{45}$ Id at 292-93.

46206 Cal App 3d 1441, 254 Cal Rptr 192 (1988) (ordered not to be officially published). 
calendar year and did not renew its policy, switching to a different insurance carrier for 1985 . The 1984 policy was a "claims made" policy which covered "claims first made against the insured and reported to the [insurer] during the policy period . . .." ${ }^{47} \mathrm{Al}$ though the claim in question was made against the insured during the 1984 policy period, the insured did not report the claim to the insurer until January 21, 1985. Nevertheless, the court ruled for the insured, concluding that a "claims made policy which requires the insurer to be notified during the policy period severely limits the scope of coverage so that the objectively reasonable expectations of the purchaser . . . are not met." 48

Since the reasonable expectations doctrine is based upon the belief that policyholders do not carefully read their policies, an ironic case is Powers $v$ Detroit Automobile Inter-Insurance Exchange. ${ }^{49}$ The policy at issue covered "the owned automobile or any non-owned automobile." But it defined a "non-owned vehicle" so as to exclude a vehicle owned by a relative. (And, presumably, an "owned vehicle" was one owned by the insured.) Thus, the insurer contended, a vehicle owned by a relative was not covered. The Michigan Supreme Court disagreed, concluding that a

person not reading the policy might not expect to be covered when driving a nonowned car, because the owner was buying insurance for the owned car only. However, once the coverage of owned and nonowned automobiles is read, the policy purchaser's reasonable expectations would be for coverage. ${ }^{50}$

The court admitted that a policyholder who did not read the policy would not have expected coverage, and of course a policyholder who read the entire policy would learn he had no coverage. But the court imagined a policyholder who reads about coverage of "nonowned vehicles" but who does not read the definition of "nonowned." This possibility was enough for the court to rule in favor of the insured. ${ }^{11}$

${ }^{47}$ Id at 193 (emphasis omitted).

${ }^{48}$ Id at 195. Ironically, the court acknowledged the relationship between cost and coverage. "[C]urrent premiums ... for claims made and reported policies are artificially low, compared to other policies, due to the insurer's cost savings from declined coverage ...." Id at 197.

49427 Mich 602, 398 NW2d 411, 424-25 (1986).

so Id at $424 \mathrm{n} 8$.

"Justice Levin's opinion in Powers went so far as to recommend that courts "determine when a policy of insurance is defective [and, therefore, unenforceable] because it does not do the job that the consumer reasonably expects it to do." Id at 432 (Levin concurring in part and dissenting in part). 
As is apparent from the cases cited, the fine print version is most frequently applied to exclusions from coverage. The Kentucky Supreme Court declared as much in holding that "the insured is entitled to all the coverage he may reasonably expect to be provided under the policy. Only an unequivocally conspicuous, plain and clear manifestation of the company's intent to exclude coverage will defeat that expectation." 52 Courts' hostility to exclusions may, however, cause insurers to modify policy designs in a way that will ultimately harm the insured. When an insurer designs a policy, it initially provides broad coverage and then selectively deletes coverage through exclusions. The alternative to the exclusion method is to start with a baseline of no coverage and then list "inclusions" that selectively provide coverage in specific situations. The "exclusion" method of policy design seems better for the insured because, in contrast to the inclusion method, it provides coverage for unanticipated situations not specifically mentioned in the policy. Courts' hostility to exclusions may encourage insurers to write policies covering only losses specifically included by policy terms; thus, judicial attempts to enforce broader coverage might in the long run produce narrower coverage.

\section{The Whole Transaction Version of the Reasonable Expecta- tions Doctrine}

The "whole transaction" version of the reasonable expectations doctrine enforces expectations created not only "by policy language and structure" (the fine print version), but also by insurers' "marketing patterns and general practices," ${ }^{3}$ the contract's clear language to the contrary notwithstanding. ${ }^{54}$

${ }_{52}$ Woodson v Manhattan Life Insurance Co. of New York, 743 SW2d 835, 839 (Ky 1987) (quoting Rowland H. Long, The Law of Liability Insurance $\S 5.10 \mathrm{~B}$ (Matthew Bender, 1966)).

ss Keeton, 83 Harv L Rev at 973 (cited in note 2).

s4 In addition to California, Colorado, Iowa, and New Jersey (the states mentioned in the text), five others use the "whole transaction" version of the reasonable expectations doctrine. (1) Alaska: Stordahl v Government Employees Insurance Co., 564 P2d 63 (Alaska 1977). (2) Arizona: Darner Motor Sales, Inc. $v$ Universal Underwriters Insurance Co., 140 Ariz 383, 682 P2d 388, 398-99 (1984); see Case Note, Insurance Law-Challenging Boilerplate Exclusions, 1984 Ariz St L J 751, 766; David L. Leitner, Enforcing the Consumer's "Reasonable Expectations" in Interpreting Insurance Contracts, 38 Fed Ins \& Corp Couns Q 379, 390-93. (3) Montana: Transamerica Insurance Co. v Royle, 656 P2d 820, 824 (Mont 1983). (4) New Mexico: Konnick v Farmers Insurance Co. of Arizona, 703 P2d 889, 893 (1985). (5) North Carolina: Great American Insurance Co. v C.G. Tate Construction Company, 279 SE2d 769, 774 (NC 1981). Wisconsin may also use the whole transaction version: see Gross $v$ Lloyds of London Insurance Co., 121 Wis 2d 78, 358 NW2d 266, 271 (1984); but for Wisconsin's application of the ambiguity version, see Kremers-Urban Co. $v$ American 
The "whole transaction" version overlaps with, but should be distinguished from, the doctrine of equitable estoppel, an element of which is the insured's reliance on a misrepresentation by the insurer. ${ }^{55}$ The whole transaction version requires no misrepresentation by the insurer.

Typical of the whole transaction version is Sparks $v$ St. Paul Insurance Co. ${ }^{56}$ in which the New Jersey Supreme Court noted that insurance policies will be enforced "only to the extent that the policy language conforms to public expectations and commercially reasonable standards." 57 Thus, a court's notion of "public expectations" about insurance coverage defeats clear policy language.

The Iowa Supreme Court has also fully accepted the whole transaction version of the reasonable expectations doctrine. In Grinnell Mutual Reinsurance Co. $v$ Voeltz, ${ }^{58}$ a homeowner's policy excluded injuries "arising out of the business pursuits of an insured person." The policy defined "business" as "any full or parttime trade, profession, or occupation." ting her niece (for $\$ 1.50$ per hour) when she left the child in a bathtub with water so hot that it burned the child.

The court refused to enforce the "business pursuit" exclusion because the agent asked and was told that the insured's occupation was baby-sitting but "made no further inquiries" of the insured when selling the policy. The court held that the agent had a duty

Employers Insurance Co., 119 Wis 2d 722, 351 NW2d 156, 163 (1984), quoted as Wisconsin law in United American Insurance Co. $v$ Wibracht, 825 F2d 1196, 1199 (7th Cir 1987).

${ }^{58}$ Keeton, 83 Harv L Rev at 978 (cited in note 2), describes estoppel as an application of the broader principle of reliance. Professor Keeton distinguishes reliance from the reasonable expectations doctrine on the grounds that reliance requires a detrimental change in position but protects insureds from an unauthorized representation by an agent in the field; the reasonable expectations doctrine applies instead to expectations "based on matters emanating from a source relatively near the command center of the insurer's operational structure." Id at 973-74. This distinction is not correct, however, because the reasonable expectations doctrine has been extended to cover expectations created by agents and others far from the insurer's "command center." See, for example, Harr v Allstate Insurance Co., 54 NJ 287, 255 A2d 208, 219 (1969).

${ }^{86} 100$ NJ 325, 495 A2d 406 (1985).

${ }^{57}$ Sparks, 495 A2d at 414 . The Sparks court acknowledged that in the following cases the New Jersey Supreme Court deprived unambiguous provisions of their literal meaning to provide coverage not warranted by the policy: Gerhardt $v$ Continental Insurance Cos., 48 NJ 291, 225 A2d 328 (1966); Allen v Metropolitan Life Insurance Co., 44 NJ 294, 208 A2d 638 (1965); Kievit v Loyal Protective Life Insurance Co, 34 NJ 475, 170 A2d 22 (1961). Sparks, 495 A2d àt 413.

${ }^{88} 431$ NW2d 783, 785 (Iowa 1988). But the court added that it had "refused to extend the principle of reasonable expectations if an ordinary person would not misunderstand his or her coverage from a reading of the policy, unless there are other circumstances attributable to the insurer which caused such expectations." Id at 786 .

s9 Id at 785 . 
to inform the insured that baby-sitting would constitute a business because "the average person would certainly not expect his or her babysitting activities to be excluded if the agent was made aware of these activities and made no further inquiries." 60 The court emphasized that "reasonable expectations . . . may be inferred from the circumstances under which the policy was provided and issued." 1

Although California courts have claimed to apply the reasonable expectations doctrine "only where the language of the policy is ambiguous," 62 even early California cases used the whole transaction version. ${ }^{63}$ The earliest case, Steven $v$ Fidelity \& Casualty Co. of New York, ${ }^{64}$ involved a policy for air travel insurance, sold through a vending machine, which excluded "TRAVEL ON OTHER THAN SCHEDULED AIR CARRIERS." The insured crashed on a charter plane, clearly outside the policy's coverage, but the court ruled for the beneficiary because "the insured may reasonably expect coverage for . . . reasonable substitute transportation necessitated by emergency." 65

Some apparent whole transaction rules may really be "fine print" versions. For instance, a Colorado Court of Appeals also requires that "[a]n insurer who wishes to avoid liability must not only use clear and unequivocal language evidencing its intent to [do so], but it must also call such limiting conditions to the attention of the [insured]." ${ }^{, 68}$ It is not clear what is required to bring a

6o Id at 788 .

61 Id. See also Moritz v Farm Bureau Mutual Insurance Co., 434 NW2d 624, 625-26 (Iowa 1989). See Leitner, 38 Fed Ins \& Corp Couns $Q$ at 387-88 (cited in note 54); Note, Reasonable Expectations: Contract Ambiguity v. Arbitrary Application, 34 Drake L Rev 1065, 1077-78 (1985-86).

62 Hallmark Insurance Co., Inc. v Superior Court, 201 Cal App 3d 1014, 247 Cal Rptr 638, 640 (1988) (citing Producers Dairy Delivery Co. $v$ Sentry Insurance Co., 41 Cal 3d 903, 226 Cal Rptr 558 (1986), and Schrillo Co. v Hartford Accident \& Indemnity Co., 181 Cal App 3d 766, 226 Cal Rptr 717 (1986)). See also State Farm Mutual Automobile Insurance Co. v Ball, 127 Cal App 3d 568, 179 Cal Rptr 644, 647 (1981) (rejecting "resort to the doctrine of reasonable expectations ... where no ambiguity exists in the language of an insurance contract.").

63 See Insurance Co. of North America v Sam Harris Constr. Co., 22 Cal 3d 409, 149 Cal Rptr 292, 583 P2d 1335, 1336 (1978); Gray v Zurich Insurance Co., 65 Cal 2d 263, 54 Cal Rptr 104, 107-08 (1966) (en banc).

64 $58 \mathrm{Cal} 2 \mathrm{~d} 862,27 \mathrm{Cal}$ Rptr 172 (1962).

6s Id at 176. See also Young $v$ Metropolitan Life Insurance Co, which disregarded unambiguous language and held that the insurer "must bring to the attention of the insured all provisions and conditions which create exceptions or limitations on the coverage." 272 Cal App 2d 453, 77 Cal Rptr 382, 387 (1969) (citation omitted).

* Leland $v$ Travelers Indemnity Co. of Illinois, 712 P2d 1060, 1064 (Colo App 1985). See also Sanchez v Connecticut General Life Insurance Co., 681 P2d 974, 977 (Colo App 
contract term to the insured's attention. If making the term "clear and conspicuous" in the written policy is sufficient, such a requirement amounts to the "fine print" version. But bringing a term to the insured's attention may require the agent to discuss the term with the insured. This would be the whole transaction version because the court is free to disregard policy language even if it cannot be dismissed as "fine print."

\section{Critique of the Reasonable Expectations Doctrine}

As noted earlier in this Comment, ${ }^{67}$ advocates of the reasonable expectations doctrine justify it on three grounds. The first is the likelihood that the insurance purchaser does not receive the actual contract, the insurance policy, until after agreeing to buy insurance and perhaps paying the first premium. ${ }^{68}$ This fact does not justify the reasonable expectations doctrine, however; it simply makes the prospective purchaser the "offeror" and the insurer the "offeree." The offeror pays a premium before acceptance by the offeree, but this will be refunded if the offeree does not accept. In addition, if a prospective insured asked for a copy of the insurer's standard form before committing to the deal, it is unlikely that any insurer would refuse. Finally, "[b]y industry practice an insurance policy can usually be cancelled prior to its expiration date without the insured incurring untoward expenses or legal consequences." ${ }^{6 \theta}$ If the policyholder receives the policy after the inception of the contract and is unhappy with the terms, he may cancel the policy. The insurer may refund the premium in full, returning the parties to their original positions, or, at worst for the policyholder, the insurer may keep a portion of the first premium to cover the time before cancellation.

The other two justifications for the reasonable expectations doctrine are more powerful: (1) the "inequality of bargaining power" between the parties to an insurance contract, and (2) the fact that insurers usually use long, complex policies with provisions over which the policyholder cannot negotiate. The remainder of this Comment will use economic analysis and freedom of contract theory to argue that these problems are chimeric, and that if they did exist, they would not be solved by the reasonable expectations

1984); Leitner, 38 Fed Ins \& Corp Couns $Q$ at $388-90$ (cited in note 54).

${ }^{67}$ See text accompanying notes 9 through 12 .

${ }^{68}$ Rahdert, 18 Conn L Rev at 329 (cited in note 4); Mayhew, 13 Pepperdine L Rev at 270-71 (cited in note 5).

${ }^{68}$ Mayhew, 13 Pepperdine L Rev at 272 (cited in note 5). 
doctrine.

A. Economic Analysis

1. The "inequality of bargaining power" rationale.

An economic analysis of the reasonable expectations doctrine seems particularly appropriate since the view that the standard form contract is used primarily by enterprises with strong bargaining power is itself a species of "economic" analysis. ${ }^{70}$ Courts and commentators frequently use the phrase "bargaining power" but they do not define it. It seems to be a euphemism for wealth. ${ }^{71}$ An insurer, for instance, is described as having superior bargaining power if it controls more assets than the policyholder with whom it contracts.

In practice, courts say that ordinary consumers and employees have less bargaining power than institutions or wealthy individuals. ${ }^{72}$ If "unequal bargaining power" is just another way of saying "unequal wealth," it is difficult to see why unequal bargaining power would support the reasonable expectations doctrine. Instead of coercing wealth transfers through the refusal to enforce contract terms-which distorts incentives and is a haphazard and costly way of transferring wealth-it seems that higher taxes combined with larger transfer payments would be a more effective way to redistribute wealth, i.e., to "equalize bargaining power." Refusing to enforce the contracts of one with little bargaining power effectively deprives that person of the right to contract, since others will be unlikely to form a contract with her when they suspect that

70 Courts adopting the view that form contracts are used primarily by those with strong bargaining power often cite Friedrich Kessler, Contracts of Adhesion-Some Thoughts About Freedom of Contract, 43 Colum L Rev 629, 632 (1943). Professor Kessler argued that "the law, by protecting the unequal distribution of property, does nothing to prevent freedom of contract from becoming a one-sided privilege. . . . Standard contracts in particular could . . . become effective instruments in the hands of powerful industrial and commercial overlords enabling them to impose a new feudal order of their own making upon a vast host of vassals." Id at 640 .

1 Rakoff, 96 Harv L Rev at 1249 (cited in note 13).

${ }^{72}$ A more helpful approach to bargaining power is advanced in Richard A. Epstein, In Defense of the Contract at Will, 51 U Chi L Rev 947, 973-77 (1984). Professor Epstein discusses the issue in the context of employment contracts but the principle applies to all contracts. According to this approach, the extent to which the insurer has improved its position added to the extent to which the insured has improved its position is the surplus created by the contract. The party with superior bargaining power, rightly understood, is the one who captures most of this surplus. This view has the important advantage of emphasizing that contracting is a positive sum game in which even the party with less bargaining power is better off with the contract than without the contract at all. 
the law will enforce only one side of the bargain.

But even many who accept the desirability of contracts between parties of unequal wealth object to such contracts, on bargaining power grounds, if they involve a standardized form such as an insurance policy. Those who invoke the "bargaining power" argument often assume that standardized forms are evidence of a powerful seller using its position in the market to the detriment of a helpless consumer. A more plausible explanation is that both parties benefit from standard forms because they greatly reduce the transaction costs of contracting. ${ }^{73}$ Professor M. J. Trebilcock has made a comprehensive economic analysis of standard form contracts.

[T] he proposition that the use of consumer standard-form contracts is the result of the concentration of market power is entirely without factual foundation. The reason why such contracts are used is . . . to reduce transaction costs. . . . [S]tandard forms are used (for this reason) in countless contexts where no significant degree of market concentration exists. . . . The fact that in these cases a supplier's products are offered on a take-it-or-leave-it basis is evidence not of market power but of a recognition that neither producer- nor consumer-interests in aggregate are served by incurring the costs involved in negotiating separately every transaction. The use of standard forms is a totally spurious proxy for the existence of market power. ${ }^{74}$

The reduction of transaction costs permitted by the use of standard forms has significant implications for the insurance industry. Not only is the insurance company able to avoid negotiating and writing individual contracts with each of its customers, but it is relieved of the supervision of its agents who actually negotiate contracts on the company's behalf. ${ }^{75}$ The increased cost of policies

${ }^{73}$ Ronald H. Coase, The Choice of the Institutional Framework: A Comment, $17 \mathrm{~J} \mathrm{~L} \mathrm{\&}$ Econ 493, 494 (1974); Posner, Economic Analysis at 102 (cited in note 12).

74 M. J. Trebilcock, The Doctrine of Inequality of Bargaining Power: Post-Benthamite Economics in the House of Lords, 26 U Toronto L J 359, 364 (1976). See also Rakoff, 96 Harv L Rev at 1218-19 (cited in note 13 ).

7s Judge Posner writes that there is an "innocent explanation" for standard form contracts: "The seller is just trying to avoid the costs of negotiating and drafting a separate agreement with each purchaser. These costs, of which the largest probably is supervising the employees and agents who engage in the actual contract negotiations on the company's behalf, are likely to be very high for a large company that has many contracts." Posner, Economic Analysis at 102 (cited in note 12)

Professor Rakoff observes: "The pressure to produce may tempt salesmen to make bar- 
in the absence of standard forms would be tremendous, and much less insurance would be written for the ordinary consumer. ${ }^{76}$ Standard form insurance policies, then, are an efficient means of reducing transaction costs and have nothing to do with bargaining power. Proponents of the reasonable expectations doctrine need to justify it on some ground other than "inequality of bargaining power." And, as already noted, even if unequal bargaining power were a problem, refusing to enforce contract terms (via the reasonable expectations doctrine) would be an ineffective means of solving it.

2. The "length and complexity of insurance policies" rationale.

Since standard forms have no relationship to bargaining power but are merely the most efficient means of providing insurance to the general public, a single justification for the reasonable expectations doctrine remains: that the terms of the standard form policies cannot be left to voluntary agreements in the marketplace because they are long, complex, and written by the insurer.

This third rationale for the reasonable expectations doctrine is based on the notion that since the seller writes the contract, it will include only terms favorable to it and onerous to the buyer ${ }^{77}$ This notion is wrong. As Judge Richard Posner explains, "[i]f one seller offers unattractive terms, a competing seller, wanting sales for himself, will offer more attractive terms. The process will continue until the terms are optimal." 78 This insight_and this Comment's application of it in the following pages-assumes a world in which

gains into which the organization is unwilling to enter; the use of standard form contracts to state the terms of the deal obviates much of the need for, and expense of, internal control and discipline in this regard." 96 Harv L Rev at 1223 (cited in note 13 ).

${ }^{76}$ Mayhew, 13 Pepperdine L Rev at 270 (cited in note 5). One commentator has stated that the insurance industry "could not cease to use standard forms without at the same time ceasing to conduct an insurance business." Conrad L. Squires, A Skeptical Look at the Doctrine of Reasonable Expectation, 6 Forum 252, 253 (1971). Another commentator points out that in addition to reducing transaction costs, use of standard forms facilitates universalized risk assessment, yielding another important cost savings. Robert H. Jerry II, Understanding Insurance Law 97 (Matthew Bender, 1987).

${ }_{77}$ "The insurance contract is carefully prepared by the insurance company with over two centuries of experience. The insured is a neophyte. He does not have the intellectual equipment to meet the challenge." Thompson $v$ Occidental Life Insurance Co. of California, 90 NM 620, 567 P2d 62, 65 (1977) (Sutin concurring in part and dissenting in part).

78 Posner, Economic Analysis at 102 (cited in note 12). Insurance is a competitive industry in the United States with thousands of insurers, over a hundred of which are major national companies. For a criticism of Posner, see Arnold L. Rotkin, Standard Forms: Legal Documents in Search of an Appropriate Body of Law, 1977 Ariz St L J 599, 602-06. 
sellers (insurers) can easily alter the terms of their form contracts. This is emphatically not the real world of insurance, in which the vast majority of insurance policies have been approved by state insurance commissioners, and rates are often regulated as well. Before incorporating the realities of the regulatory regime into the analysis, it may be helpful first to consider a world in which both prices and terms of insurance policies are unregulated.

For example, assume that certain consumers wish to purchase insurance. One insurer decides to charge price $\mathrm{P}$, and offers a standard form contract with (from the consumers' perspective) harsh terms. Another insurer will find it in its interest to pursue the consumers' business by offering, again at price $\mathrm{P}$, terms which are slightly easier. This process will continue until the marginal cost to the insurer of easing the terms equals the marginal gain (as a result of attracting more of the consumers' business) from doing so. If $\mathrm{P}$ is not the optimal price, we can expect competition to push prices, as well as terms, to their optimal levels. For example, consumers may be willing to pay more for easier terms. If so, insurers will find it in their interest to raise premiums and provide more coverage until the marginal benefit to the consumers of additional coverage, i.e., easier terms, is equal to the marginal cost of that coverage which is passed along to the consumer in higher prices. ${ }^{79}$ At the point of optimal prices and optimal contract terms, "[a]ll the firms in the industry may find it economical to use standard contracts and refuse to negotiate with purchasers."

Professor Victor Goldberg criticizes this reasoning and concludes that competition among sellers is not likely to produce optimal contract terms. He envisions instead competition among sellers focusing on price, at the expense of contract terms.

$[\mathrm{T}]$ he cost of acquiring and processing information on contract terms is much greater than for price; unless the firm intentionally makes the particular term an important selling point-as is sometimes the case with the length or inclusiveness of the warranty-few, if any, customers will perceive the existence of variations in terms. ${ }^{81}$

${ }^{79}$ See Coase, $17 \mathrm{~J} \mathrm{~L} \&$ Econ at 494 (cited in note 73).

${ }^{80}$ Posner, Econamic Analysis at 102 (cited in note 12).

${ }^{81}$ Victor P. Goldberg, Institutional Change and the Quasi-Invisible Hand, $17 \mathrm{~J} \mathrm{~L} \&$ Econ 461, 485 (1974). Professor Goldberg goes on to say that only a few customers will find it worthwhile to obtain information on contract terms, and that insurers would be able to discriminate in favor of these aggressive customers while insulating others from the benefits. As Professors Schwartz and Wilde point out, however, discriminating among customers in such a manner is quite difficult, and even if these customers could be identified, drafting 
As Professor Ronald Coase has noted, however, if an insurer "lower[s] its price, simultaneously reducing the coverage of its policies," its competitors should be capable "of explaining that, although the other firm's price is lower, its coverage is inferior and that those who shift their business will be worse off . ..."82 (Those who shift their business to the low price/harsh term insurer are worse off because, by Professor Goldberg's assumption, the optimal terms are higher price/easier term.) Professor Coase persuasively counsels skepticism of Professor Goldberg's world in which "[c]onsumers never become aware of the deception and competitors, who have the strongest motives for informing consumers of the true state of affairs, never succeed in doing so." 83

But will competitors provide consumers with the optimal amount of information? In theory, yes, as competitors will continue to provide additional information as long as consumers are willing to pay for it. $^{84}$ But Professor Trebilcock suggests that there is a public goods aspect to such information. In other words, it may be difficult to prevent those (consumers of insurance) who do not incur the costs of obtaining information, but who derive value from it, from using it. Consequently, producers of this information (competing insurers) would perceive the demand for information about terms other than price to be lower than it "really" is and would produce suboptimal information..$^{85}$ Competition, therefore, would focus on price and result in a bias toward low price/harsh term policies.

While the possibility of marginally suboptimal information-and, therefore, low price/harsh term policies-is the worst outcome the market is likely to generate, there are strong indications that even these problems do not exist. For instance, the public goods argument about information may be weak as applied to

individualized contracts would likely be prohibitively expensive. See Alan Schwartz and Louis L. Wilde, Intervening in Markets on the Basis of Imperfect Information: A Legal and Economic Analysis, 127 U Pa L Rev 630, 638 (1979).

${ }^{82}$ Coase, $17 \mathrm{~J} \mathrm{~L} \&$ Econ at $494-95$ (cited in note 73 ).

83 Id at 495 .

34 As Professor Trebilcock notes: "On the demand side, a consumer will be making a rational investment in information if he invests resources in search and evaluation of information to the point where the expected marginal benefits from further search and evaluation are equal to the marginal costs of further such activity. On the supply side of the market in information, a supplier will be producing for consumers of his products and services a socially optimal amount of information about them if the price which consumers are prepared to pay for the marginal benefits of this information is equal to the marginal social costs (in terms of real resources consumed) of producing it." $26 \mathrm{U}$ Toronto $\mathrm{L} \mathrm{J}$ at 371-72 (cited in note 74) (footnote omitted). 
the real insurance world. How often do insurers fail to provide information about (i.e., disparage) their competitors because they do not expect to reap the benefits of doing so? While conveying the information to unknown prospective first-time buyers may be difficult, many insurance contracts, particularly renewals, are formed in the context of a continuing relationship between the insured and an insurer through an insurance agent or broker. It seems that if an insurer points out its competitor's flaws, the customer, after being convinced about the competitor, will probably remain with this insurer rather than search for a third insurer.

Another factor preventing insurers from receiving high premiums for harsh standard form policies is the price that most consumers attach to uncertainty. Assuming a prospective insured is risk averse (a reasonable assumption, since she is buying insurance) and suspects that the fine print of the insurance policy-which she does not plan to read-will tend to benefit the insurer, she will pay less for this policy than for the same policy minus the fine print. ${ }^{86}$ Thus, in the aggregate, it is unlikely that harsh terms allow insurers, as a group, to exploit insureds, as a group, because the latter have discounted the price they are willing to pay for insurance to account for the possibility that a harsh term might hurt them.

Buyers' tentativeness has given rise to another market mechanism that mitigates the possible bias towards low price/harsh term policies caused by an alleged underproduction of information: the "easy to read" policy summary, which is most often offered with group policies. Policyholders do not find it cost-effective to read carefully the entire policy but they fear the presence of harsh terms. This tension can be resolved by a clear and concise summary of the policy terms. Courts have properly held that "[w]here a conflict exists between a master policy and other informational resources prepared and distributed at the insurer's behest, . . . insureds are not bound by more restrictive provisions in the policy." "87

se Id at 376 .

${ }^{87}$ Romano v New England Mutual Life Insurance Co., 362 SE2d 334, 340 (W Va 1987). Recently a California court said that it will "consider advertising copy and brochures issued by the insurance company describing the coverage in determining a purchaser's 'reasonable expectations.' " Thus an insurer "may be required to provide coverage according to its advertising, despite more restrictive provisions in the insurance contract itself." Suarez v Life Insurance Co. of North America, 206 Cal App 3d 1396, 254 Cal Rptr 377, 382 (1988). Holding the insurer liable for its false advertising seems uncontroversial if such advertising is done with intent to deceive (fraud) or negligently (negligent misrepresentation), already 
Another powerful argument against government intervention (whether or not in the form of the reasonable expectations doctrine) is that even if the market is biased toward low price/harsh term policies, it is not biased toward low price/harsh term results. That is, consumers will often get a better deal than the contract requires. This is because businesses have powerful incentives to please their customers. In selecting insurance, consumers may commonly respond to standard forms by ignoring them and focusing on insurers' business reputations, considering among other things an insurer's "reputation for settling claims without requiring extensive documentation or hiding behind 'technical' clauses." than contract terms may be based on an assumption that an insurer's practices will often be more favorable to the policyholder than the standard form would require. As Professor Rakoff has noted, "Such an assumption may well be valid, because businessmen concerned with fostering goodwill do not always stand on a document that was from the beginning overdrafted by lawyers."

Insurers have an incentive to compete to develop a good claims-adjustment reputation and often refrain from invoking the policy's fine print to deny coverage even when it authorizes them to do so. ${ }^{90}$ Perhaps insurers like to have fine print with which to defeat a claim on technical grounds when they really object to the claim on substantive grounds-apparent arson, for instance-that are costly and difficult to prove. To the extent that this is so, policyholders are quite rational in ignoring the fine print because they predict, often correctly, that if they deal with their insurers in good faith the insurers will not risk a bad reputation in the market by sticking to the fine print. Thus, it is a misleading oversimplification to compare insurance policies only on the basis of premiums and policy terms, since the insurer's application of those terms is equally important. Some insurers, generally older companies that sell through independent local agents, have reputations for generous claims practices. Other insurers, sometimes the relatively new

common law torts.

s8 Rakoff, 96 Harv L Rev at 1227-28 (cited in note 13).

so Id at 1228 (footnote omitted).

90 One survey of property insurance policies in Champaign-Urbana, Illinois, found that $28 \%$ of all those on real property and $55 \%$ on jointly-owned real property were void under the terms of the policy because the "sole and unconditional ownership clause" was violated. George Goble, The Moral Hazard Clauses of the Standard Fire Insurance Policy, 37 Colum L Rev 410, 418 (1937). To suggest that insurers actually stood on this clause to deny such a high percentage of claims is beyond belief. 
direct writers, have reputations for stingy claims practices. Consumers rightly consider such reputations as well as premiums and policy terms when making insurance purchases.

A final argument against intervention is that courts (along with legislative/administrative regulation) created the problem in the first place. As several commentators have noted, "the courts have been the chief architects of a great bulk of the verbose and highly technical policy language." inherently intricate enough to require a fairly complicated policy. But "contract drafters look[] to judicial decisions to isolate legal words of art and phrases whose import [can] be predicted with a reasonable degree of certainty [and] policyholders, in turn, fashion[] imaginative arguments to combat the effects of unfavorable provisions." ${ }^{92}$ When the courts adopt an imaginative interpretation of policy language in order to provide coverage that would not be warranted under a more conventional reading of the policy, the insurer's policy drafters return to the drawing board. The drafters' attempts to confine coverage to prevent judicial expansion may result in increasingly long and complex policies. ${ }^{93}$ Perhaps courts could help to clarify policy language by intervening less-not more.

\section{The failings of government intervention.}

The assertion that there is less than optimal information and, therefore, a bias toward low price/harsh term policies in the market is necessarily inconclusive, depending as it does on speculation about preferences that people supposedly have but do not reveal by their behavior. This discussion has shown, however, that even if the market produces suboptimal prices and overly harsh terms, this outcome does not deviate far from the optimal one.

Even if the free market does produce information significantly below the optimal level, such inefficiencies are probably less than those that would result from government intervention, particularly if such intervention takes the form of the reasonable expectations doctrine. If markets do induce insurers (or any drafter of standard form contracts) to supply somewhat less than optimal information,

a1 E. Neil Young, John R. Lewis, and J. Finley Lee, Insurance Contract Interpretation: Issues and Trends, Insurance L J 71, 72 (1975).

${ }^{92}$ Id.

93 For an example of this process, see the discussion of the standard of proof in dishonesty policies in Ace Wire \& Cable Co., Inc. $v$ Aetna Casualty \& Surety Co., 60 NY2d 390, 457 NE2d 761, 763-64 (1983). See also Jerry, Understanding Insurance Law at $97-98$ (cited in note 76 ). 
this does not mean that greater efficiency will result from judicial, or other governmental, intervention.

Professor Trebilcock recognizes several government responses to the market's supposedly suboptimal information. One possibility is, essentially, the reasonable expectations doctrine: "judicially imposed liability (non-enforceability) on a supplier who fails to make his contractual provisions reasonably intelligible to the average consumer . . . ."94 Another is "[l]egislated conspicuousness standards . . . [or] disclosure provisions."

But as Professor Trebilcock notes:

A major problem in all of these approaches lies in determining whether consumers perceive the marginal benefits of possessing more information (what kinds, how much, what form?) to be greater than the marginal social costs, including law-making and enforcement costs, entailed in providing it. Experience with mandatory disclosure requirements has not been encouraging. ${ }^{96}$

Efficiency requires more information only as long as the marginal benefits of doing so continue to exceed the marginal costs. However, the only indication of the consumers' need for increased information is what they are willing to pay for it. Speculating that consumers "value" increased information more than they reveal by their behavior in the market does nothing to reveal how much more and, consequently, it is impossible for a judge or anyone else to correctly meet this indiscernible need for information.

Courts, moreover, are particularly unsuited to providing the incentives needed to produce the correct amount of additional information. When analyzing insurance contracts, a court must decide whether or not to enforce a particular term; its decision must be either "yes" or "no." Judicial decision-making cannot implement the slight changes in the degree to which consumers are informed, and in the price they pay to be informed, necessary to reach the optimal amount of information. The courts thus employ a blunt instrument where only a fine adjustment would improve upon the market, as Professor Trebilcock himself concludes. ${ }^{97}$

${ }^{94}$ Trebilcock, $26 \mathrm{U}$ Toronto L J at 373 (cited in note 74).

${ }^{96}$ Id.

${ }^{96}$ Id at 373 .

97 "If substantive intervention is to occur, this may argue for general, ex ante, legislative intervention where 'harsh' terms are invalidated and the market is permitted to take care of consequential adjustments to other terms." Trebilcock, $26 \mathrm{U}$ Toronto $\mathrm{L} \mathrm{J}$ at 376 
If efficiency is the goal, any possible benefits from increased information must be weighed against the costs. These include not only the cost to the supplier (insurer) of providing increased information but also the costs to the legal system of intervening. ${ }^{98}$ Such costs include not just the obvious ones, such as diverting more of society's resources to the judicial process, but also the less tangible "error costs" of mistakes by the courts.

Thus far, this Comment has suggested that judicial non-enforcement of standard form contract terms through the reasonable expectations doctrine is more likely to hinder than to advance economic efficiency. ${ }^{9 \theta}$ However, this Comment has yet to analyze legislative/administrative intervention. ${ }^{100}$ Having explored the interrelationship between prices and terms in a free market, one can adjust for the presence of regulation. The simplest form of regulation to analyze, and a common form in practice, is the mandated policy in which all the terms are prescribed by the insurance commission or other regulatory body. If the required policy has easier terms than the policy that would have been written in a free market ("market terms"), the insurers will raise premiums above the price they would have charged without regulation. Conversely, if the required policy has harsher terms than the market terms, competition will encourage insurers to lower their premiums below the unregulated market level.

If the required terms are easy compared to the market terms and insurers are not allowed to raise their premiums accordingly, insurers' profits will suffer and they will ultimately be forced to

${ }^{\text {98 }}$ Id at 373.

${ }^{9 \theta}$ Economic analysis is, however, likely to call for judicial intervention in standard form contracts that are not only complex but fraudulent, i.e., where the drafter deliberately creates confusion. "Where a contract is so worded or arranged that the supplier knows or should know that the other party does not understand its implications, and he knows or should know that the other party reasonably entertains other understandings as to its legal incidents, perhaps based on prevailing contractual practices elsewhere in the market, to allow him to sign the contract without correcting these misunderstandings is tantamount to misrepresentation and thus conducive to suboptimal allocative decisions." Trebilcock, $26 \mathrm{U}$ Toronto L J at 370-71 (cited in note 74). Professor Trebilcock approves a "rule against unfair surprise ... [which] would deal with contractual documents which in their wording or organization are apt to mislead consumers." Id at 371.

100 Professor Goldberg opposes judicial intervention, calling instead for administrative or legislative intervention since the gains from a lawsuit frequently are insufficient to cover. the claimant's litigation costs. "Realizing this, frms would have little incentive to remove unenforceable terms from their contracts." Goldberg, $17 \mathrm{~J} \mathrm{~L} \mathrm{\&} \mathrm{Econ} \mathrm{at} 488$ (cited in note 81). Other advocates of administrative over judicial intervention include Arthur A. Leff, Contract as Thing, 19 Am U L Rev 131, 149-55 (1970); Rotkin, 1977 Ariz St L J at 613-24 (cited in note 78 ). 
pull out of the market for this line of insurance. If, on the other hand, the required terms are harsher than the market terms and regulation prevents insurers from lowering premiums accordingly, prospective policyholders at the margin will go without insurance. Although they are willing to agree to a price/term combination that unregulated insurers would be willing to provide, regulation prevents the consummation of the deal.

The analysis becomes more complex if the terms are only partially regulated. An insurer (or, more likely, group of insurers) may propose a policy to the state regulatory body which approves of most of the terms but requires some changes. If the changes make the policy easier than the proposed (market) policy, the insurers may compensate, as already discussed, by raising premiums. Or they may be able to persuade the regulator to approve some changes in another portion of the policy to make that term harsher, thus balancing the required first change. Or the insurer may adjust both premiums and other terms in response to the required change. (Of course, this process would work in reverse if the regulator required a change to make the terms harsher than the insurers proposed.)

The most important conclusion from this admittedly abstract analysis is that legislative/administrative intervention cannot, in the long run, benefit policyholders in the aggregate. Whatever a regulation gives, in the form of lower premiums or easier terms, it takes away in harsher terms or higher premiums (or some combination of the two). And if the regulation attempts to restrict both prices and terms in favor of the policyholder, it will eventually drive insurers out of the market. In an attempt to give policyholders more insurance for the money, such regulation would deprive at least some prospective policyholders of insurance entirely.

If, however, one were unpersuaded by this Comment and believed that suboptimal information biases the market toward low price/harsh term policies so severely that the high costs of government intervention were worth incurring, this analysis indicates that the reasonable expectations doctrine would not be the proper form of intervention. The government intervention most likely to promote efficiency would be prohibition of harsh terms, leaving premiums to the free market. If the regulator could keep each term from rising above a certain "level of harshness" so that the policy as a whole became easier and prices were allowed to rise to compensate for this, the regulator could, in theory, correct any bias toward low prices and harsh terms. As already noted, however, it is doubtful that the market is significantly biased toward low price/ 
harsh term policies; even if it were, it is likely that this regulation, too, would in practice hamper efficiency.

\section{B. Freedom of Contract}

Economic analysis counsels abandonment of the reasonable expectations doctrine by undermining its justifications, "unequal bargaining power" and the insurer's incentives to draft contracts with excessively harsh terms. This section will argue that even if bargaining power or contract terms did favor the insurer, one would still have to reject "freedom of contract" and weaken the rule of law in order to justify the reasonable expectations doctrine.

The freedom of contract model starts with the premise, fundamental to liberalism, that our duties to others (except the duty to respect their rights to liberty and property) should be voluntarily assumed, rather than imposed upon us by the state or by other means of coercion. ${ }^{101}$ Even one who rejects this premise and advocates the imposition of some duties to do for others, rather than only to refrain from harming them, may decide that providing another with insurance is not a duty that should be imposed. If one believes that this particular duty should be assumed only voluntarily, then one must hold that the reasonable expectations doctrine should be abandoned. ${ }^{102}$

This conclusion follows from the traditional understanding of contract law: the duties assumed by the parties are to be determined from the language of the written contract, so long as it was signed by the parties in the absence of force or fraud. The reasonable expectations doctrine, of course, often imposes duties on the insurer additional to those stipulated in the contract. Advocates of the reasonable expectations doctrine argue, however, that the ap-

101 Freedom of contract "guarantee[s] to individuals a sphere of influence in which they will be able to operate, without having to justify themselves to the state or to third parties." Richard A. Epstein, Unconscionability: A Critical Reappraisal, 18 J L \& Econ 293 (1975).

102 The reasonable expectations doctrine does not actually impose on anyone a duty to insure another. It only imposes this duty on those who choose to become insurers and, indirectly, on their customers. The doctrine says, in effect, that people may become insurers, but only if they meet certain requirements imposed by the state. Many forms of insurance regulation are similar in this respect. Professor Rahdert notes that "the freedom-of-contract complaint, if taken seriously, would prove too much, because the same point could be made about any form of insurance regulation, from the traditional doctrines of equity, to administrative regulation, to legislative prescription." Rahdert, 18 Conn L Rev at 368 (cited in note 4). All these forms of regulation do impinge on freedom of contract but, as the following pages of text show, the reasonable expectations doctrine is particularly inimical to freedom of contract because it alters rights and duties $e x$ post, in a highly subjective and uncertain manner. 
propriate measure of duties is not the written contract-since the insured has not truly consented to the duties specified in the contract-but the insured's "reasonable expectations." Thus, even if one accepts the premise that contract law ought to enforce those duties - and only those duties - that one has voluntarily undertaken, the crucial question of what constitutes the "voluntary" assumption of a duty remains. ${ }^{103}$ Those advocates of the doctrine who accept the "voluntary" premise of liberalism implicitly argue that the insurer has voluntarily consented to providing the insured with whatever coverage the latter could reasonably expect.

The traditional, and superior, view is that one's signature on a contract constitutes the "voluntary" assumption of those duties, and only those duties, specified by the terms of that contract. As stated by Judge Learned Hand, the traditional rule is that "[a] man must indeed read what he signs, and he is charged if he does not ...."104 (In the modern insurance context, the policyholder does not sign the insurance policy itself, which is the actual contract. The prospective policyholder signs the application for insurance, which is an offer to purchase insurance on the terms specified in the policy. ${ }^{105}$ Thus, signing the application for insurance has the same force, under traditional legal rules, as signing any contract.)

Rejection of this traditional rule is implicit in any attempt to justify the reasonable expectations doctrine. But the case in favor of the rule that one's signature equals assent to the contract's terms is compelling. The great advantage of this "bright line" rule is the large measure of objectivity and certainty it creates. This objectivity and certainty as to what obligations the courts will enforce are an integral part of the "rule of law," which Professor Hayek defined as a system of "rules which make it possible to foresee with fair certainty how the [state] authority will use its coercive powers in given circumstances and to plan one's individual affairs on the basis of this knowledge."106 The high degree of objectivity and certainty required by the rule of law promotes

${ }^{103}$ Anthony T. Kronman, Contract Law and Distributive Justice, 89 Yale L J 472, 478 (1980).

${ }^{194}$ Gaunt v John Hancock Mutual Life Insurance Co., 160 F2d 599, 602 (2d Cir 1947). See also Note, 57 NYU L Rev at 1192 (cited in note 14).

${ }^{105}$ This should not seem unusual as people often purchase products sight unseen. The insurance contract is a product, like an item in a mail order catalog, that the purchaser will not receive until after agreeing to the contract of sale. And, as discussed in the text at note 69 , the policyholder can generally cancel his policy at little cost if he is dissatisfied with its terms when it arrives.

${ }^{10}$ Friedrich A. Hayek, The Road to Serfdom 72 (U Chicago, 1944). 
three important values: equality, freedom, and wealth. To the extent that the equation of one's signature with her assent makes contract interpretation a clear and objective process, it insures that the law is applied equally by protecting us from the imposition of duties by a judge or jury's whim. Freedom, too, is served by clear and objective rules if we hold, with Kant, that "[m]an is free if he needs to obey no person but solely the laws."107 Finally, clear and objective rules-such as treating one's signature as assent to a contract-promote economic growth since they encourage long-term decisions and investments by giving economic actors confidence that they can predict how the state will use its coercive powers.

Professor Spencer Kimball has made some of these points as they apply to insurance contracts and the reasonable expectations doctrine in particular:

[J]udicial, as distinguished from legislative, intervention renders costs quite unpredictable and makes insurers fearful, tightening the market. Legislative intervention can destroy a market, too. Yet, recurring judicial activism ... can have an even more disruptive effect. Whereas legislative intervention is prospective, judicial intervention has a retroactive effect. This creates greater uncertainty, giving insurers no opportunity to react in a timely fashion to the changes in the legal environment. ${ }^{108}$

In contrast to the traditional rule's objectivity and certainty, inquiry into an insured's "reasonable expectations" is highly subjective and uncertain. ${ }^{109}$ Even proponents of the reasonable expectations doctrine concede that, as applied in practice, it is less certain than the rule equating the policyholder's signature with her assent. $^{110}$

${ }^{107}$ Quoted in id at 82.

108 Kimball, 19 Conn L Rev at 315 \& n 24 (citation omitted) (cited in note 26 ).

108 Where tests of "reasonableness" are involved, "it becomes impossible to tell where liberty ends and obligation begins; where contract ends and tort begins." Richard A. Epstein, A Theory of Strict Liability, 2 J Legal Stud 151, 199 (1973). As the Pennsylvania Supreme Court said, "We believe that the burden imposed by [the reasonable expectations doctrine] fails to accord proper significance to the written contract, which has historically been the true test of parties' intentions. By focusing on what was and was not said at the time of contract formation rather than on the parties' writing, [the doctrine] makes the question of the scope of insurance coverage in any given case depend upon how a factfinder resolves questions of credibility. Such a process, apart from the obvious uncertainty of its results, unnecessarily delays the resolution of controversy, adding only unwanted costs to the cost of procuring insurance." Standard Venetian Blind Co. v American Empire Insurance Co., $503 \mathrm{~Pa} 300,469$ A2d 563, 567 (1983).

110 Rahdert, 18 Conn L Rev at 370 (cited in note 4). Professor Jerry, an opponent of the 
If one's signature (obtained without force or fraud) constitutes voluntary consent to the duties specified in the written contract, then a court's refusal to enforce policy language imposes duties on the parties to which they did not consent and deprives them of rights to which they are entitled. Thus, the reasonable expectations doctrine - to the extent that it trumps contractual language-is an affront to freedom of contract.

Advocates of the reasonable expectations doctrine often respond to freedom of contract concerns by asserting that there is no freedom of contract where "adhesive" standard forms are used. This response rests in part on the view that traditional contract rules, including the signature rule, have applied, and should apply, only where there is oral bargaining between parties of roughly equal sophistication and bargaining power:

The doctrine that courts do not lightly interfere with freedom of contract must be applied cautiously and realistically with regard to complex contracts of insurance, since such contracts are highly technical, extremely difficult to understand, and not subject to bargaining over the terms. ${ }^{111}$ The reasonable expectations doctrine does interfere with the illusion of freedom of contract. But as to the insured there was never any with which to interfere. Whatever the economic and social justifications for the adhesion contract of insurance, the reasonable expectations doctrine simply does not operate at any level to displace mutually agreed-upon terms. ${ }^{12}$

There is, however, nothing in the principles underlying freedom of contract which suggests that it should be confined to agree-

\footnotetext{
"four-corners" approach to contract interpretation, recognizes that under such a rule "judicial decisions are more predictable; insurers are more confident about how their policies will be interpreted; coverage questions can be more quickly resolved; costs can be reduced-both in administration of policies and in litigation - and these savings redound to the consumer's benefit." Jerry, Understanding Insurance Law at 98 (cited in note 76). Revealingly, Jerry says insurers can be confident in predicting the rights and duties that the law will enforce. But the rule benefits all contracting parties. If the policyholder reads the policy, she too can better predict what a court will require. Judge Keeton asserts that an objective test for determining the reasonableness of expectations "produces an essential degree of certainty and predictability about legal rights ..." 83 Harv L Rev at 968 (cited in note 2). This Comment exhibits skepticism of the claim that leaving every judge and jury free to decide for themselves what is "reasonable" will produce a high degree of certainty.

111 Sparks $v$ St. Paul Insurance Co., 100 NJ 325, 495 A2d 406, 412 (1985).

112 Rahdert, 18 Conn L Rev at 368 (cited in note 4). See Mayhew, 13 Pepperdine L Rev at 290 (cited in note 5) ("The answer to the [freedom of contract argument] is simple-the insurance policy does not contain bargained-for terms."). See also Note, 57 NYU L Rev at 1196 (cited in note 14). which advocates Karl Llewellyn's view that a standard form "'re-
} 
ments in which there is dickering over all terms. ${ }^{113}$ As already discussed, the premise of freedom of contract is that people ought to be free to enter into whatever agreements they mutually desire and contract law should enforce only those duties that people have voluntarily assumed. ${ }^{114}$ If contracting parties are acting voluntarily-in the absence of force or fraud-other people, including those in government, should let the parties determine their rights and duties toward each other. Freedom of contract applies to standard form insurance policies just as it applies to any other contracts. The prospective policyholder may sign the application for insurance, or, if she does not wish to sign it, she is free to walk away. ${ }^{115}$

Any argument that she is not "truly" free to walk away ultimately reduces to an assertion that some people have a right to insurance. ${ }^{116}$ If these people cannot persuade an insurer to volunta-

sults in two several contracts: the dickered deal, and the collateral one of supplementary boiler plate.' The terms of the latter contract, given only a general assent by the consumer, would be honored to the extent that (1) they do not undercut the meaning of the bargainedfor-terms, and (2) they are not manifestly unfair" (quoting Llewellyn, The Common Law Tradition at 371 (cited in note 14)).

113 "It is, of course, no objection to application of the 'ordinary' rules of contract law that the terms to be enforced were not bargained." Rakoff, 96 Harv L Rev at 1251 n 246 (cited in note 13). This is demonstrated by "the rules of offer and acceptance, which require that the acceptance not deviate from the offer, and which make bargaining history presumptively irrelevant." Id.

114 "The libertarian theory of contract law is premised upon the belief that individuals have a moral right to make whatever voluntary agreements they wish for the exchange of their own property, so long as the rights of third parties are not violated as a result." Kronman, 89 Yale L J at 475 (cited in note 103).

116 This refutes Professor Rakoff's claim that "individual freedom, insofar as it is [relevant to form contracts], supports the claim of the adhering party not to have the drafter's terms imposed on him." Rakoff, 96 Harv L Rev at 1238 (cited in note 13). The flaw in this argument, of course, is that a contract cannot be "imposed" on anyone who is free to walk away. The desperate economic situation of one signing a contract does not make his assumption of the contract duties any less voluntary, unless his situation was caused by people violating his rights. See Robert Nozick, Anarchy, State and Utopia 262 (Basic, 1974) ("Whether a person's actions are voluntary depends on what it is that limits his alternatives. If facts of nature do so, the actions are voluntary. (I may voluntarily walk someplace I would prefer to fly to unaided.) Other people's actions place limits on one's available opportunities. Whether this makes one's resulting action non-voluntary depends upon whether these others had the right to act as they did.").

${ }^{110}$ This assertion is incompatible with liberalism's premise that one's duties to do for others should be assumed only voluntarily. See text at notes 102-104. The reasonable expectations doctrine is a step from contractual-based duties and entitlements to status-based duties and entitlements. Professor Rahdert believes "the step is warranted by the special role that insurance plays in our society. Status-based duties are by no means unusual in insurance law . . . [because] insurance is a business affected with a strong public interest [and] . . . is important . . to the state . . as $a[n] \ldots$ alternative to government-funded social compensation." Rahdert, 18 Conn L Rev at 376-77 (cited in note 4). Professor 
rily agree to provide this measure of insurance, the government-perhaps through its courts-must force other people (insurers and, indirectly, other policyholders) to provide 1t. Under this view, the reasonable expectations doctrine requires courts to forcibly redistribute wealth from some policyholders, through insurers, to other policyholders. ${ }^{117}$

[The] notion that the development of the [reasonable expectations] doctrine may have the effect, or even the intention, of mandating coverage that would not otherwise be available in the market is speculative but plausible. . . . Instead of being redistributed through taxation, wealth or income is redistributed by compulsory cross-subsidies within the insurance mechanism. ${ }^{118}$

Even if coerced wealth transfers are desirable, they should not be pursued through judicial modification of insurance contracts. ${ }^{119}$ As Professor Kimball notes, "[s]ocial goals should be achieved in ways other than cross-subsidization within the insurance system, which works badly enough as a pure market system without being burdened with solving the ills of the world at the same time."120

The government can force some people to provide others with insurance that they could not have obtained through voluntary transactions in the market. Legislators can do this through statesponsored insurance programs if they can raise the revenues needed for funding. Or the courts can do this through the reasonable expectations doctrine, which is funded by a (less visible) "tax" on insurers and, ultimately, other policyholders. ${ }^{121}$ For the reasons

Rahdert advocates the reasonable expectations doctrine and other status-based duties as a way for the state to force some people to insure other people without, it should be noted, openly taxing the former to fund insurance for the latter.

117 The thesis that the reasonable expectations doctrine is primarily a wealth transfer mechanism is supported by those cases where it is used to defeat or "interpret" policy language written, not by the insurer, but by a government regulator. In those cases there can be no claim that the insurer is using a form policy to exploit its bargaining power or hide harsh terms, since the insurer does not write the policy. For example, see National Union Fire Insurance Co. v Reno's Executive Air, Inc., 100 Nev 360, 682 P2d 1380, 1383 n 1 (1984).

11 Kimball, 19 Conn L Rev at 314-15 (cited in note 26).

119 See text at notes 71-74.

${ }^{220}$ Id at 322 .

121 Perhaps advocates of coerced wealth transfers prefer schemes like the reasonable expectations doctrine to conventional revenue generation (i.e., taxation) precisely because the former is less visible, though no less painful, to the taxpayer. Those potential and actual policyholders who are the victims of the reasonable expectations doctrine may mistakenly believe that the increases in their insurance premiums mean greater profits for insurance companies when those increases are really a judicially imposed tax to fund a redistribution of wealth to those litigants who broaden their insurance coverage through the reasonable 
stated, the legislative alternative would do less harm to the values protected by freedom of contract and the rule of law.

\section{CONCLUSION}

This Comment has explained the development of the reasonable expectations doctrine, focusing on the perceived problems that advocates of the doctrine sought to correct. It concluded that the "ambiguity" version of the doctrine should be abolished because it adds nothing to previous approaches to insurance contracts and confuses the meaning of the term "reasonable expectations doctrine." The "fine print" and "whole transaction" versions of the doctrine should also be abolished because the problems they are supposed to cure are not, in fact, problems at all. Furthermore, economic efficiency, freedom of contract, and the rule of law are particularly endangered by judicial regulation of insurance contracts. The words of one federal court are most appropriate.

There is no logic nor reason to create an obligation contrary to and beyond the clear, plain language of a policy and Professor Keeton provides none. To create such would oblige a party at the whim of one whose personal interests are served by the conversion of an expectancy to a right. It would permit the rewriting of a contract by a court, without limitation except by what is reasonable for an insured to expect. There is no more reason, logic nor justification to enlarge an insurance policy to match an insured's expectations than to permit the rewriting of any contract .....122 